\title{
Medium-range mid-tropospheric transport of ozone and precursors over Africa: two numerical case studies in dry and wet seasons
}

\author{
B. Sauvage, F. Gheusi, V. Thouret, J.-P. Cammas, J. Duron, J. Escobar, C. Mari, P. Mascart, and V. Pont \\ Laboratoire d'Aérologie, Toulouse, France \\ Received: 6 February 2007 - Published in Atmos. Chem. Phys. Discuss.: 5 April 2007 \\ Revised: 27 July 2007 - Accepted: 4 October 2007 - Published: 17 October 2007
}

\begin{abstract}
A meso-scale model was used to understand and describe the dynamical processes driving high ozone concentrations observed during both dry and monsoon season in monthly climatologies profiles over Lagos (Nigeria, $6.6^{\circ} \mathrm{N}$, $3.3^{\circ} \mathrm{E}$ ), obtained with the MOZAIC airborne measurements (ozone and carbon monoxide). This study focuses on ozone enhancements observed in the upper-part of the lower troposphere, around $3000 \mathrm{~m}$. Two individual cases have been selected in the MOZAIC dataset as being representative of the climatological ozone enhancements, to be simulated and analyzed with on-line Lagrangian backtracking of air masses.

This study points out the role of baroclinic low-level circulations present in the Inter Tropical Front (ITF) area. Two low-level thermal cells around a zonal axis and below $2000 \mathrm{~m}$, in mirror symmetry to each other with respect to equator, form near $20^{\circ} \mathrm{E}$ and around $5^{\circ} \mathrm{N}$ and $5^{\circ} \mathrm{S}$ during the (northern hemisphere) dry and wet seasons respectively. They are caused by surface gradients - the warm dry surface being located poleward of the ITF and the cooler wet surface equatorward of the ITF.
\end{abstract}

A convergence line exists between the poleward low-level branch of each thermal cell and the equatorward low-level branch of the Hadley cell. Our main conclusion is to point out this line as a preferred location for fire products - among them ozone precursors - to be uplifted and injected into the lower free troposphere.

The free tropospheric transport that occurs then depends on the hemisphere and season. In the NH dry season, the AEJ allows transport of ozone and precursors westward to Lagos. In the NH monsoon (wet) season, fire products are transported from the southern hemisphere to Lagos by the southeasterly trade that surmounts the monsoon layer. Additionally ozone precursors uplifted by wet convection in the ITCZ can also mix to the ones uplifted by the baroclinic cell and be advected up to Lagos by the trade flow.

Correspondence to: $\mathrm{F}$. Gheusi

(ghef@aero.obs-mip.fr)

\section{Introduction}

Tropical ozone (hereafter $\mathrm{O}_{3}$ ) controls atmospheric chemical composition and affects global climate and air quality through large scale redistribution. Over the Tropics, Africa is an important reservoir of ozone precursor sources allowing ozone to build up through active photochemistry exacerbated by high solar radiation. The most important sources of ozone precursors over equatorial Africa are biomass burning (Marufu et al., 2000), biogenic (Jaeglé et al., 2005) and lightning (Schumann and Huntrieser, 2007). These sources present a strong regional seasonality. In particular, biomass burning products have substantial influence on $\mathrm{O}_{3}$ mixing ratios (Jonquières et al., 1998). These emissions account for half of the global carbon monoxide (CO) emissions (Andreae, 1993). Furthermore according to Marufu et al. (2000) pyrogenic emissions account for $16 \%$ of the ozone burden over Africa through burning of different land types (mostly savannas, forest and agricultural wastes) in the northern hemisphere from November to March and in the southern hemisphere from May to October. The dynamic processes allow redistribution of such emissions on a more global scale. During the TRACE-A campaign, plumes loaded with high $\mathrm{O}_{3}$ over the Atlantic were attributed to biomass burning emissions from Africa (Singh, 1996). More recently high CO mixing ratios over the Indian Ocean have been attributed to African biomass burning (Edwards, 2006). It is then important to understand processes affecting redistribution of such emissions.

Over Africa like in other tropical regions a major circulation pattern is formed by the trade winds blowing from subtropical highs and converging towards the equator to form the Inter Tropical Convergence Zone (ITCZ) where vertical redistribution occurs. The continental north-easterly trade in north-hemispheric Africa is called Harmattan. Due to the shape of the continent a meridional land-sea contrast exists between western Africa and the Atlantic. This surface temperature gradient, that is especially enhanced during the

Published by Copernicus Publications on behalf of the European Geosciences Union. 
northern-hemispheric summer (May to September), induces a south-westerly monsoon flow affecting the Gulf of Guinea. During the same season the African Easterly Jet (AEJ), centered at $650 \mathrm{hPa}$, blows over north equatorial Africa (Hastenrath, 1985). The AEJ is maintained in association with two diabatically forced meridional circulations, one associated with deep convection (equatorward edge), the other to dry convection (poleward edge), in the ITCZ and Saharan heat-low region respectively (Thorncroft and Blackburn, 1999; Parker et al., 2005). An overview of the major flows can be seen in Sauvage et al. (2005), their Fig. 1, at three different tropospheric levels.

According to Sauvage et al. (2005), biomass burning is responsible for high lower-tropospheric $\mathrm{O}_{3}$ mixing ratios in monthly mean during dry (December to February, DJF) and monsoon (June to August, JJA) seasons, over West and Central equatorial Africa. The persistent $\mathrm{O}_{3}$ enhancements were measured with the MOZAIC airborne programme downwind of emissions over a 1997-2004 period, and were related with a Lagrangian study using ECMWF monthly analysis to transport inside Harmattan and AEJ flows during the dry season and inside trades flow during the monsoon season. However from this previous work, it is not clear how air masses loaded with high $\mathrm{O}_{3}$ and precursors can be measured near $600-650 \mathrm{hPa}$ both in JJA and DJF, and particularly how precursors can be uplifted at the altitude of the AEJ during the dry season, and in the upper part of the lower troposphere during the wet season. The main objective of the present study is to understand the mechanisms responsible for this uplift.

These processes could not be investigated in the climatological study of Sauvage et al. (2005). First, the backtrajectories calculations were not including diffusive and convective transport. Second, the connection between ozone enhancements, main dynamical flows and fire events, all persistent on monthly average, were realized using monthly wind ECMWF analysis. Neither back-trajectories calculations using monthly ECMWF analysis, nor back-trajectories calculations using $6 \mathrm{~h}$ ECMWF analysis were able to capture the injection processes. Therefore the goal of the present study is to investigate and to improve the understanding of the dynamical meso-scale processes which allow to inject air masses loaded with biomass burning emissions, into the upper part of the lower troposphere. In order to perform this work, we focus on two cases chosen in the MOZAIC database, as being representative of the $\mathrm{O}_{3}$ enhancements history underlined in Sauvage et al. (2005), in terms of both dynamics and chemical structure of the atmosphere (altitude location of the ozone enhancement and origin of the enhancement). The first case is representative of the ozone enhancement at Lagos during the dry season, connected with African northern hemisphere biomass burning through Harmattan and AEJ flow. The second case is representative of an ozone enhancement at Lagos during monsoon season, connected with southern hemispheric biomass burning through the trade flow. Moreover the two case studies present similar ozone mixing ratio compared to the climatologies study, i.e. inside one standard deviation or at the upper limit of the set of case studies used in the climatological averages. For this purpose we adopt the approach of numerical modeling at the meso- $\alpha$ scale in association with on-line Lagrangian backtracking of air masses (backtrajectories). This model allows to resolve dynamical processes such as turbulence and convection, on the contrary of Sauvage et al. (2005) back-trajectories calculations. The numerical set-up and Lagrangian method are described in Sect. 2. Sections 3 and 4 present the dry- and wet-season case-studies, respectively. The conclusions are summarized in Sect. 5.

\section{Model specifications}

The numerical simulations are performed with the MesoNH system - a non-hydrostatic anelastic mesoscale model jointly developed by the Laboratoire d'Aérologie (Toulouse, France) and CNRM (Météo-France). The dynamical core of the model is described in Lafore et al. (1998). A terrainfollowing vertical coordinate $(\hat{z})$ is used to include orography, based on altitude levels and the Gal-Chen and Sommerville (1975) transformation. Subgrid turbulence is parameterized with a $1 \mathrm{D}, 1.5$-order scheme using the turbulent kinetic energy as prognostic variable (Cuxart et al., 2000) and the Bougeault and Lacarrère (1989) vertical-mixing length.

The warm-cloud microphysics scheme is of Kessler (1969) type including water vapor and liquid water in the form of non-precipitating cloud droplets or rain. The influence of model resolution on its ability to capture the convection through resolved or sub-grid cloud schemes is discussed by Guichard et al. (2004) (see also references therein, and Tost et al., 2006). Given the model resolution used here, the subgrid convection is parameterized with a 1-D mass flux scheme (Bechtold et al., 2001). The surface scheme is ISBA (Interactions between the Soil, Biosphere and Atmosphere, Noilhan and Planton 1989) and TEB (Town Energy Budget, Masson 2000). The radiation scheme is described in Morcrette (1991).

The trajectory calculations are based on an online method detailed in Gheusi and Stein (2002) (see also http://mesonh.aero.obs-mip.fr/mesonh/dirdoc/ lagm4521mai2004/lagrangianm45/). The trajectories take into account sub-grid transport from turbulence and convection.

Complete references and comprehensive documentation can be found on http://mesonh.aero.obs-mip.fr.

In this study we use a model domain of $7500 \times 7500 \mathrm{~km}^{2}$ with a horizontal resolution of $50 \mathrm{~km}$. The model has 72 stretched $\hat{z}$-levels up to $20 \mathrm{~km}$, with a vertical resolution of $50 \mathrm{~m}$ near the surface gradually increasing to $400 \mathrm{~m}$ in the first $6 \mathrm{~km}$. The time step is $90 \mathrm{~s}$. ECMWF analyses are used for model initialization and lateral boundary coupling every 

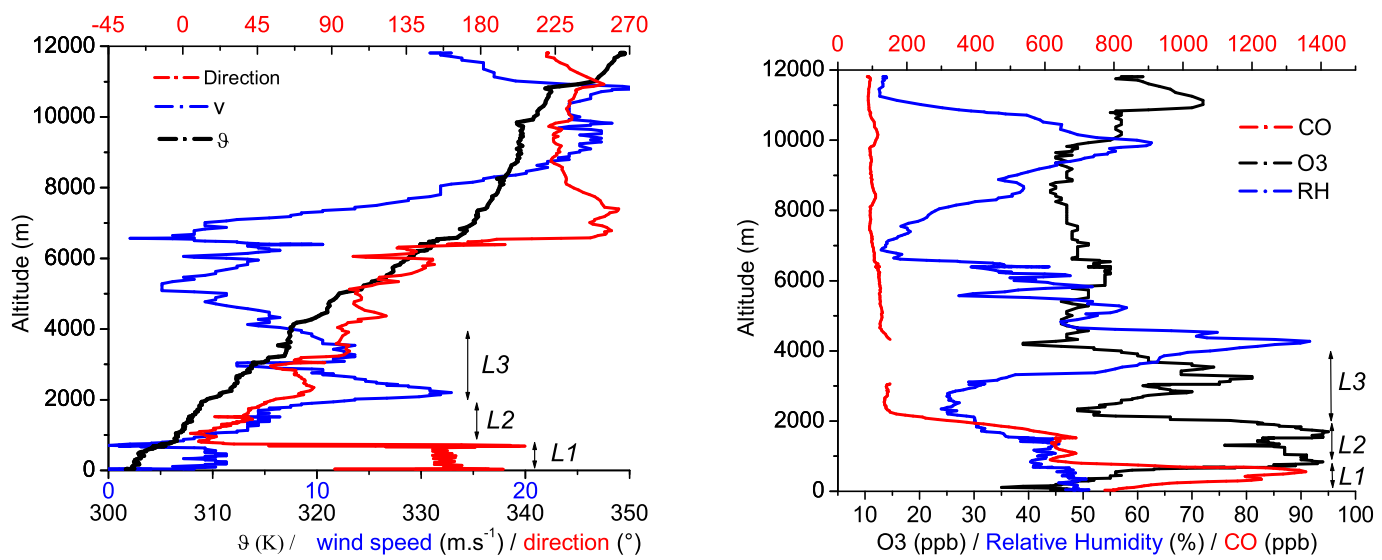

Fig. 1. MOZAIC descent profiles from the flight landed at Lagos airport on 30 January 2002, 17:00 UTC: potential temperature $(\theta)$, wind speed and direction, 0 is for northerly winds, 180 for southerly winds (left panel); ozone $\left(\mathrm{O}_{3}\right)$ and carbon monoxide $(\mathrm{CO})$ mixing ratios and relative humidity (right panel). Ozone and relative humidity share the same axis.

6h. Unfortunately it was not possible in the version of our model to constrain the simulation by MOZAIC data assimilation.

\section{Dry season case: 26-31 January 2002}

\subsection{In-situ MOZAIC profiles}

The first studied case is motivated by the data of a MOZAIC aircraft landed at Lagos airport, Nigeria $\left(6.6^{\circ} \mathrm{N}, 3.3^{\circ} \mathrm{E}\right)$, on 30 January 2002, around 17:00 UTC. Figure 1 shows the MOZAIC vertical profiles of chemical $\left(\mathrm{O}_{3}, \mathrm{CO}\right.$ and relative humidity) and dynamical parameters (wind speed and direction, potential temperature) recorded during the aircraft descent. Three polluted layers have been identified from these MOZAIC vertical profiles as described below.

A first layer (hereafter L1) below $850 \mathrm{~m}$ above sea level (a.s.l.) is a coastal boundary layer with south-easterly $\left(165^{\circ}\right)$ wind of about $5 \mathrm{~m} / \mathrm{s}$ and relative humidity around $50 \%$. The CO mixing ratio is maximum ( $800-1400 \mathrm{ppbv})$. A steep gradient in ozone connects low values (30-40 ppbv) near the surface up to the high values ( $90 \mathrm{ppbv}$ ) on top. L1 is clearly vertically bounded from the capping airmass by a temperature inversion between 850 and $1000 \mathrm{~m}$ (visible in Fig. 1 as a sudden increase of $\theta$ and sudden drop in relative humidity and rotation of wind).

A stable layer (L2) is present between 1000 and $2000 \mathrm{~m}$ a.s.l., delimited below and above by temperature inversions. The dry (humidity less than $45 \%$ ) northerly to north-easterly flux $\left(10^{\circ}-60^{\circ}\right)$ is typical of the Harmattan flow. Layer L2 is actually the continuation in altitude of the Harmattan ground layer that blows (northeasterly) north of the Inter Tropical Front (ITF) then takes off in it and surmounts $\mathrm{L} 1$. Both $\mathrm{O}_{3}$ and $\mathrm{CO}$ mixing ratios are high in $\mathrm{L} 2$ (80-95 ppbv and 500-800 ppbv, respectively).
A relative minimum of $\mathrm{O}_{3}$ separates $\mathrm{L} 2$ from the third layer of interest (L3) above, between 2100 and $4100 \mathrm{~m}$ a.s.l. L3 is driven by an easterly jet $\left(75-95^{\circ}\right)$ - the AEJ - peaking at $15 \mathrm{~m} / \mathrm{s}$ at about $2300 \mathrm{~m}$ a.s.l. Ozone mixing ratio ranges between 50 and 80 ppbv.

Within few kilometers above these three layers, $\mathrm{O}_{3}$ and $\mathrm{CO}$ are more homogeneously distributed with typical "background" values (50 and $110 \mathrm{ppbv}$, respectively) measured at these altitudes in monthly mean (Sauvage et al., 2005).

The characteristics of L1 and L2 are interpretable as follows. L1 is formed by a coastal airmass that has recently transited at low levels over the Gulf of Guinea. The high CO is likely due to offshore oil-fires as well as local emissions from the densely urbanized coastal area. The $\mathrm{O}_{3}$ gradient can reflect surface deposition and destruction processes by concentrated nitrogen oxides (expected to accompany the $\mathrm{CO}$ emission). L2 shows the highest $\mathrm{O}_{3}$ concentration but less $\mathrm{CO}$ (nevertheless exceeding $500 \mathrm{ppbv}$ ) than L1. This chemical signature reflects older airmass, driven by the Harmattan from inland where biomass burning has been detected by the satellite ATSR (http://dup.esrin.esa.int/ionia/wfa/index. asp) and MODIS (http://modis-fire.umd.edu/data.asp) instruments in the preceding days.

Above these layers the origin of high $\mathrm{O}_{3}$ in L3 (a climatological feature) is not as straightforward to explain, in particular how ozone and precursors are injected into the AEJ . Recent and local pollution can be excluded because of the low CO concentration - close to the tropospheric "background". Moreover in order to investigate the possible influence of local pollutants that could occur during the collapse of the boundary layer at night, we realized different sensitivity tests by releasing in model particles at different times from a $100 \mathrm{~km} \times 100 \mathrm{~km}$ box centered on Lagos between the surface and $500 \mathrm{~m}$ above. None of those tests have shown an uplift of local tracers above $1000 \mathrm{~m}$. On the contrary, if 

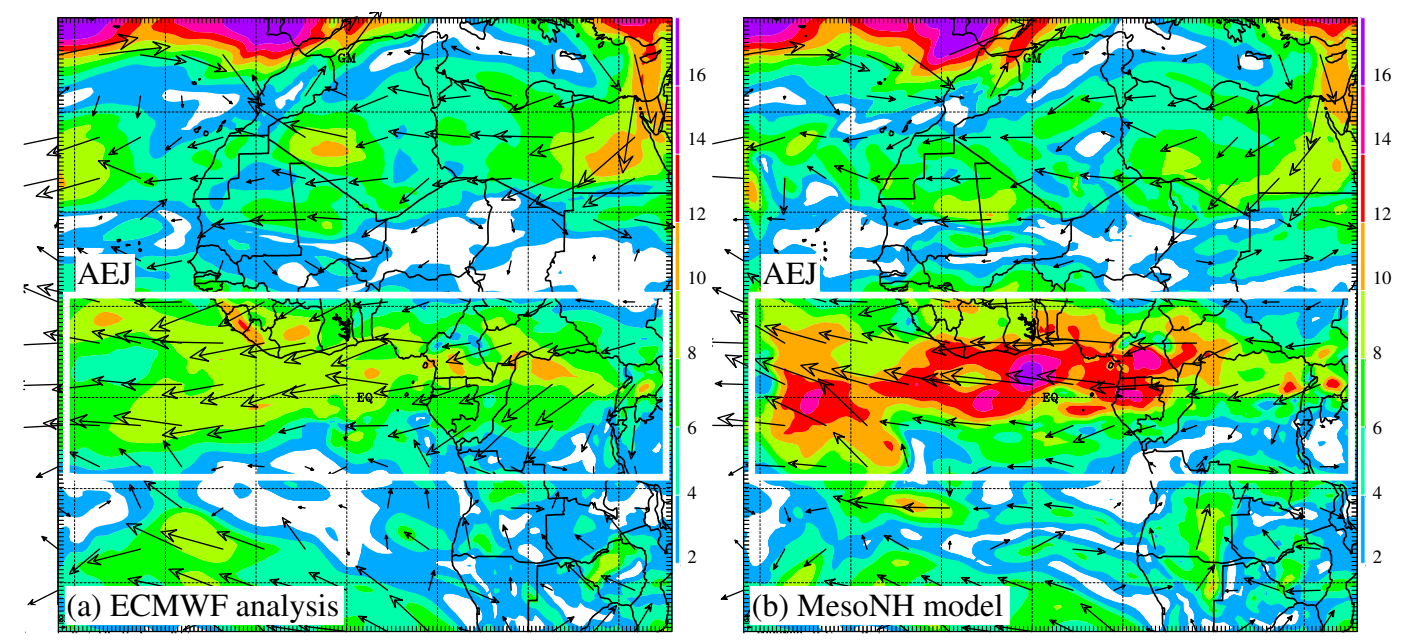

Fig. 2. Wind speed (colorscale in $\mathrm{m} / \mathrm{s}$ ) and vectors at $\mathrm{z}=3000 \mathrm{~m}$ a.s.1. on 30 January 2002, 18:00 UTC: (a) ECWMF analysis; (b) MesoNH $(+102 \mathrm{~h})$. (The white boxes highlight features under interest in the text.)

released from the biomass burning region to the northeast of Lagos, particles are rapidly uplifted in the ITF area and then advected by the Harmattan flow up to L2. Finally, no upward transport has been observed that could allow interaction between L2 and L3. These layers present hence distinct origins.

Note that the monthly climatological study of Sauvage et al. (2005) was only showing two $\mathrm{O}_{3}$ layers: a surface layer (L1) with a steep gradient, and a thick maximum of $\mathrm{O}_{3}$ corresponding to both the Harmattan and AEJ layers. Moreover the ozone monthly average within the AEJ layer (Sauvage et al., 2005) was showing only one ozone peak due to smoothing by the average methodology, in contrast with the three distinct peaks in the present case study. These peaks illustrate the fine scale stratification of the atmosphere (Newell et al., 1999). L3 has a distinct origin, as will be demonstrated in the following section by means of a numerical model.

\subsection{Model evaluation}

The model started about 4 days before the MOZAIC flight landed, on 26 January 2002, 12:00 UTC, and ran during 102 $\mathrm{h}$ until 30 January, 18:00 UTC. Such a duration allows transport at the continental scale. In this section we check whether the model has not dynamically departed from ECMWF analyses and MOZAIC observations.

Figure 2 presents a comparison of the model vs. analysis wind field on 30 January 18:00 UTC at $z=3000 \mathrm{~m}$, corresponding to the core of the ozone-rich layer $\mathrm{L} 3^{1}$. The dynamical structure of the AEJ (boxed in the figure) appears to

\footnotetext{
${ }^{1}$ Note that $3000 \mathrm{~m}$ just corresponds here to a drop in the observed wind speed (Fig. 1). This feature is however quite specific to this MOZAIC profile. Usually only a single easterly jet is visible between $2000 \mathrm{~m}$ and $4000 \mathrm{~m}$. Therefore we present the comparison at $\mathrm{z}=3000 \mathrm{~m}$, which is a typical altitude for the AEJ speed maximum. We nevertheless checked the sensitivity to height of the re-
}

be qualitatively captured by the model. The maximum wind speed values in the simulation however suffer from some overestimation compared to the analysis.

Figure 3 represents vertical profiles of wind at Lagos from the ECMWF analysis, the MesoNH simulation and the MOZAIC data. The simulated wind is smoother (broader extrema and of less amplitude) than the MOZAIC wind due to coarser vertical resolution in the model (about 50 to $400 \mathrm{~m}$ ) than for the sampling of MOZAIC data (about $30 \mathrm{~m}$ ). The ECMWF profiles present about the same limitation. However the major features for wind speed (Fig. 3a) are qualitatively well captured by the model: low wind in layer L1, minimum just below $1000 \mathrm{~m}$, wind around $7-8 \mathrm{~m} / \mathrm{s}$ in L2, maximum (AEJ, layer L3) at about $2500 \mathrm{~m}$ (however with some underestimation, around $3 \mathrm{~m} / \mathrm{s}$ ). A second maximum centered at $3500 \mathrm{~m}$ is simulated higher $(4500 \mathrm{~m})$ by the model with also $3 \mathrm{~m} / \mathrm{s}$ underestimation. The largest deviation from observed wind occurs between 7000 and $11000 \mathrm{~m}$ but the dynamics at those levels is out of interest in this study. Moreover it must be kept in mind that a MOZAIC vertical profile corresponds for the aircraft to a horizontal path of few hundred kilometers, so the comparison makes little sense for the highest levels. Regarding wind direction (Fig. 3b), the agreement is rather good for L1 and L3 with less than $20^{\circ}$ difference. The easterly component in the Harmattan layer (L2) appears however overestimated in the model by $40^{\circ}$. Finally during the 4-days run the model has not deviated much from the coupling ECMWF analyses. Both simulation out-

sults of Fig. 2. The wind fields at $3500 \mathrm{~m}$ are very similar to those in Fig. 2. At $\mathrm{z}=2500 \mathrm{~m}$, an easterly jet is also visible at about the same latitude for both simulation and analysis, with a better agreement regarding wind speed than at higher altitude. However the analyzed wind has a northerly component that is not simulated by MesoNH (this is visible in Fig. 3). 


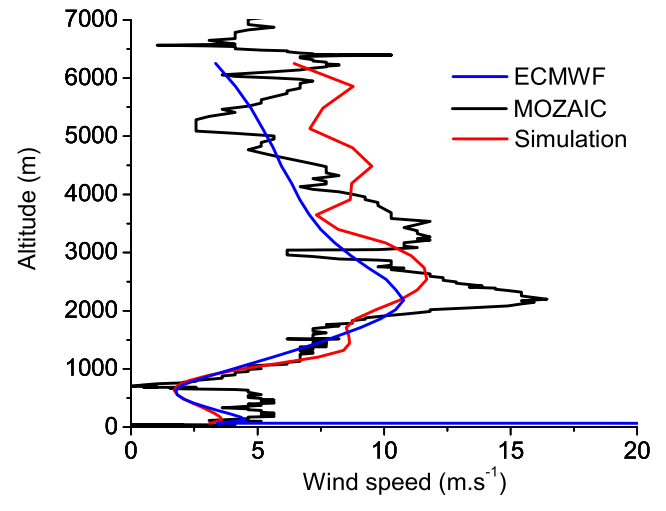

(a)

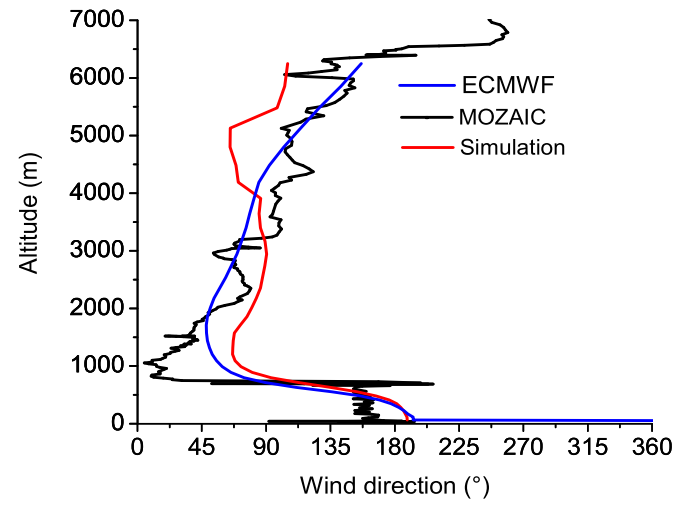

(b)

Fig. 3. MOZAIC descent profiles (black, landing 30 January 2002, 17:00 UTC) and analyzed (ECMWF) and simulated (MesoNH) vertical profiles over Lagos (red, 30 January 2002, 18:00 UTC): (a) wind speed (m/s); (b) wind direction $\left({ }^{\circ}\right.$ ).
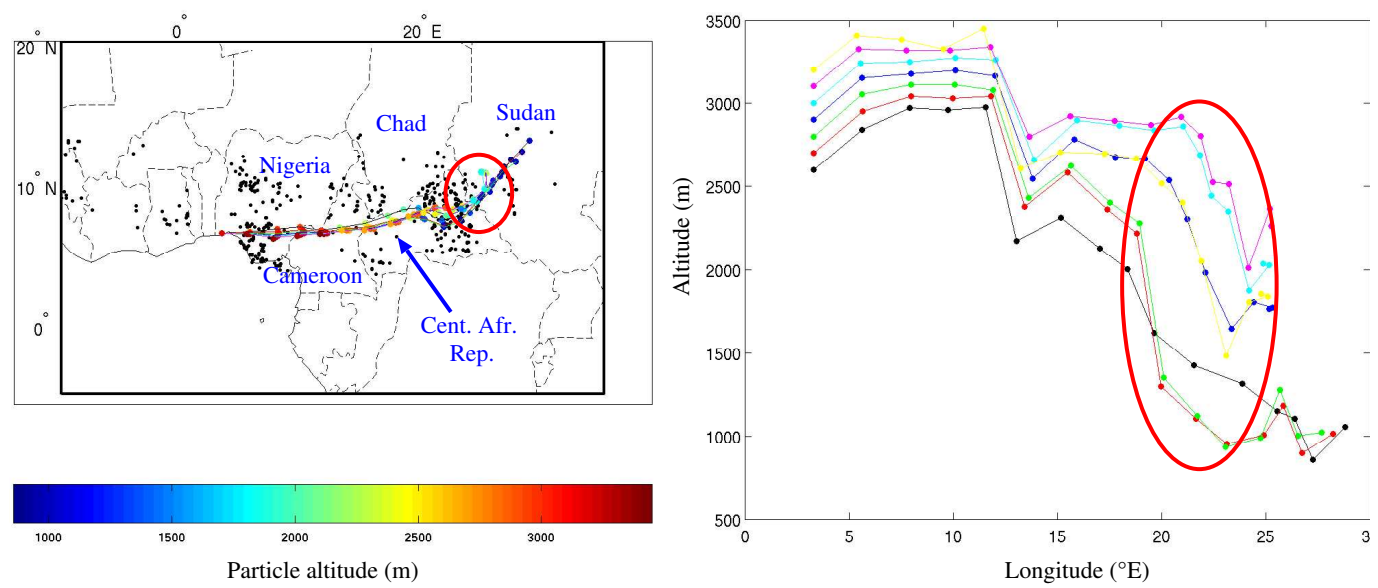

Fig. 4. Backtrajectories starting on 27 January 2002, 00:00 UTC, and ending over Lagos on 30 January 2002, 18:00 UTC. Timestep: 6h. Left panel: horizontal projection. The colorscale indicates the altitude of the particle. The black dots mark biomass fires detected by ATSR between the 26th and 29th of January 2002. Right panel: west-east vertical projection.

puts and analyses provide a reasonable realistic view of the low-tropospheric dynamics. In particular the most important for our goal is the ability of the model to reproduce the AEJ layer (L3), as we will focus now on the origin of the corresponding enriched ozone layer. To this purpose a study based on back-trajectories is presented in the following subsection.

\subsection{Airmass origin}

A cluster of 90 -h backtrajectories (i.e. back in time to the simulation start) ending above Lagos on 30 January 18:00 UTC in the altitude range $2800-3400 \mathrm{~m}$ (ozone maximum in L3) is presented in Fig. 4. The airmass appears to remain coherent over the period. On 27 January the particles are located to the south-west of Sudan at lower levels $(900-2500 \mathrm{~m})$. All the particles are uplifted by at least $1000 \mathrm{~m}$ between 27/01 18:00 UTC and 29/01 00:00 UTC.
Then in the next two days they are transported westward quasi-horizontally by the AEJ up to Lagos. In order to assess the sensitivity of the trajectories to the differences between observation and model seen in Fig. 3, we also performed backtrajectories using different ending times $( \pm 6 \mathrm{~h})$ and locations $\left( \pm 1^{\circ}\right)$ close to Lagos (not shown). The here described origin and path of the trajectories remain robust to these changes.

The uplift (circle in Fig. 4a) occurs over south-western Sudan and eastern Central African Republic (CAR), a region where savanna fires take place (see fire pixels in Fig. 4, or also http://dup.esrin.esa.int/ionia/wfa/index.asp; http://modis-fire.umd.edu/data.asp). This uplift can therefore explain the injection of fire products into the AEJ.

Figure 5a provides details of the dynamics at $1500 \mathrm{~m}$ a.s.l. with the vertical displacement of air parcels integrated over 

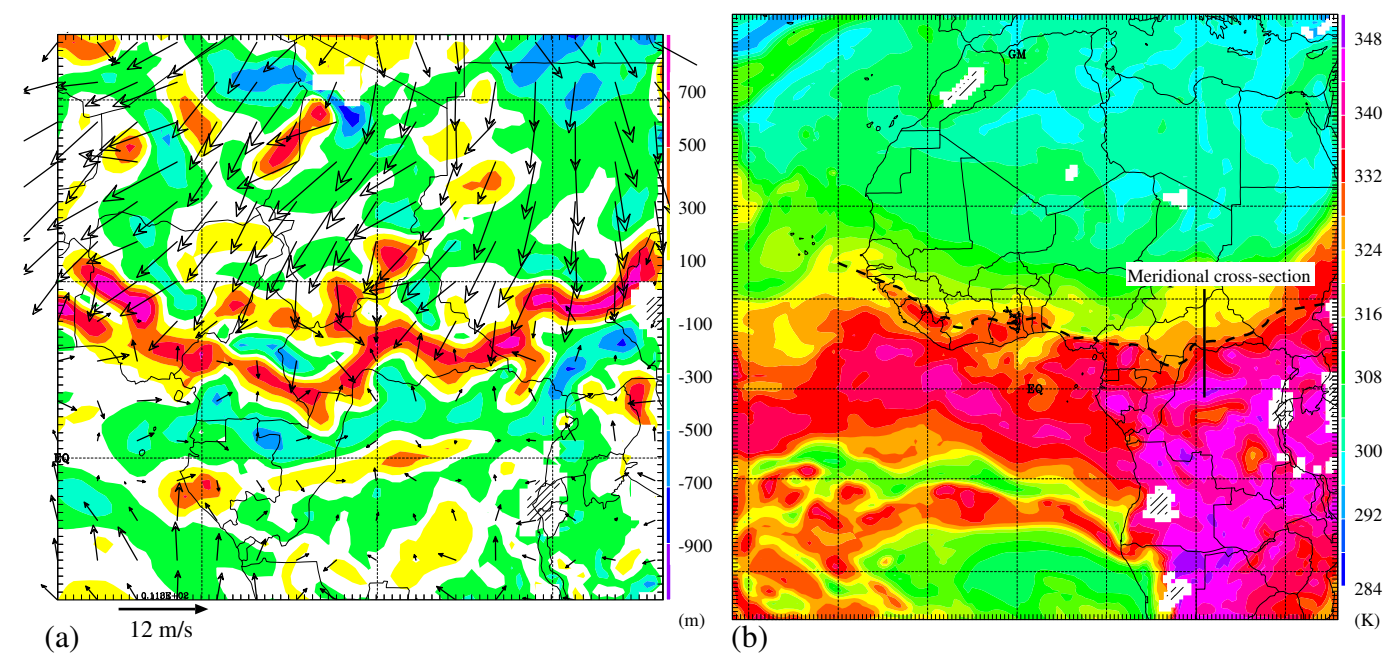

Fig. 5. (a) Air vertical displacement at $\mathrm{z}=1500 \mathrm{~m}$ (m) from 27 January 2002 18:00 UTC until 28 January 00:00 UTC, and wind vectors on 27 January 18:00 UTC $20 \mathrm{~m}$ above ground level. (b) Equivalent potential temperature $(\mathrm{K})$ at 18:00 UTC, $\mathrm{z}=1500 \mathrm{~m}$. The dashed line $\left(\theta_{e}=336 \mathrm{~K}\right)$ marks the intertropical front (ITF) and the solid segment locates the vertical cross-section considered in Fig. 6.

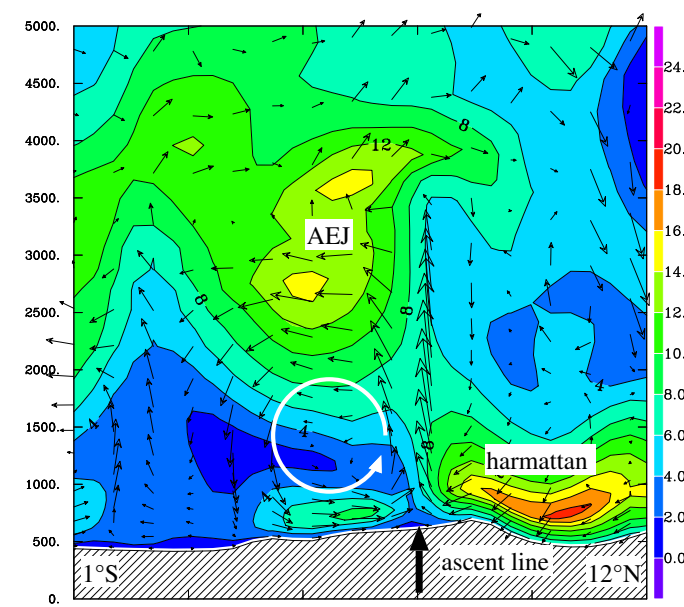

(a)

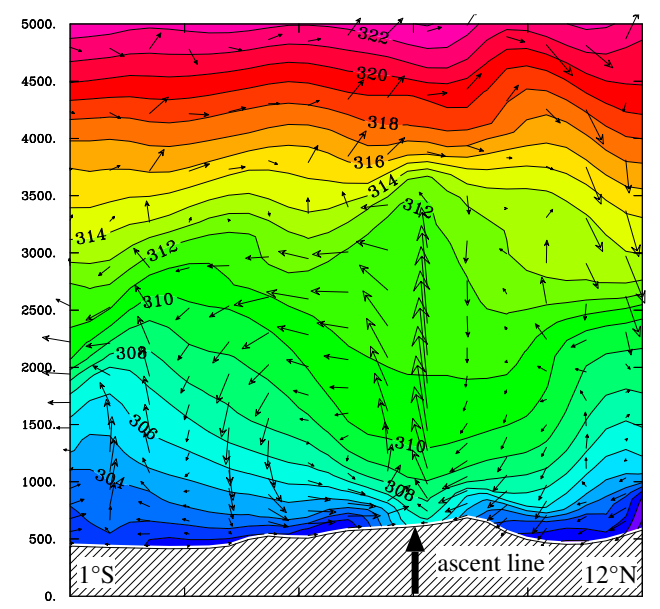

(b)

Fig. 6. Meridional vertical cross-section at $22^{\circ} \mathrm{E}$ (see location in Fig. 5b) on 28 January 2002, 00:00 UTC. (a) Longitudinal wind component (vectors) and total wind speed (colorscale in $\mathrm{m} / \mathrm{s}$ ). (b) Potential temperature (colorscale in $\mathrm{K}$ ) - vectors as in (a).

the $6 \mathrm{~h}$ preceding 28 January 06:00 UTC. This diagnostic actually shows more coherent and significant structures than instantaneous vertical velocity (highly variable spatially and temporally). A sharp line of ascent meanders from southern Sudan to Nigeria through CAR and Cameroon. It is doubled on its southern side by a broader region of subsidence. The ascent line also marks the southern limit of the Harmattan (north to northeasterly wind). Finally it coincides with the the isoline $\theta_{e}=336 \mathrm{~K}$ (Fig. 5b), used by some authors (Jonquières et al., 1998) to delimit the Inter Tropical Front (ITF).

In this case the uplift is not induced by humid convection, rare during the dry season. Indeed the $3 \mathrm{~h}$ infra-red METEOSAT data (not shown) does not show clouds during that period. The ITCZ extends to the south of the ITF, in the humid sector of the equatorial forests. Moreover no convective process occurred in the model at the place and date of the particles uplift.

Figure 6 represents meridional vertical cross-sections of winds and potential temperature. It provides more details on the dynamics related to the ascent line and to the AEJ. The wind component in the vertical plane (vertical component of vectors exaggerated for visibility) clearly exhibits a closed vertical circulation on the southside of the ascent line, with the low-level branch (ground level-1000 ma.s.l.) oriented northwards and the return branch in altitude (1500-3000 m) southwards. The dipolar ascent/subsidence regions depicted 

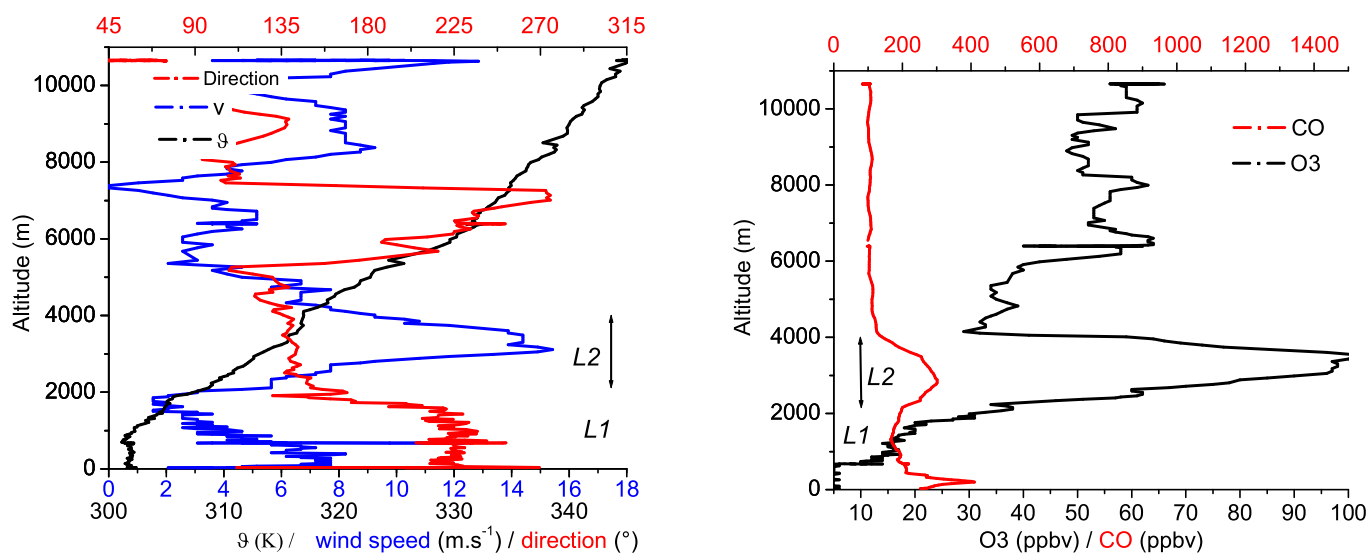

Fig. 7. MOZAIC descent profiles from the flight landed at Lagos airport on 14 July 2003, 15:30 UTC: potential temperature ( $\theta$ ), wind speed and direction (left panel); ozone $\left(\mathrm{O}_{3}\right)$ and carbon monoxide $(\mathrm{CO})$ mixing ratios (right panel).

in Fig. 5a correspond to the upward/downward branches. The potential temperatures (Fig. 6b) highlight the baroclinic nature of this circulation in response to a surface gradient of temperature (the warm region being to the north) opposite to those of humidity and biomass cover.

The whole pattern should be viewed as a baroclinic solenoidal circulation (to some extent comparable to a coastal sea breeze but at a larger horizontal scale, of about $500 \mathrm{~km}$ ). The AEJ is located just above the return branch and indeed corresponds to the geostrophic adjustment (thermal wind balance) to the northward horizontal gradient of temperature (visible below $2500 \mathrm{~m}$ a.s.l. in Fig. 6b) causing the circulation. The dynamics depicted here is in full agreement with the dynamical model proposed for the maintenance of the AEJ by Thorncroft and Blackburn (1999) by means of an idealized two-dimensional numerical model, and confirmed by Parker et al. (2005) based on high-resolution dropsonde measurements.

Finally the ascent line is much thinner and stronger than the descending branch. This is due to the low-level convergence (below $1000 \mathrm{~m}$ a.s.l.) of the southerly "breeze" and northerly Harmattan flows.

In conclusion the path taken by the studied cluster of trajectories - namely uplift from the low levels in the ITF then transport by the AEJ - can explain the strong concentration of $\mathrm{O}_{3}$ in the AEJ over equatorial West Africa highlighted by the MOZAIC climatology. In effect the described scenario does not rely on particular features of the studied case, but on a quasi-stationary low-tropospheric circulation with a wide zonal extension over almost all the continent. Indeed meridional cross sections at different day and time (not shown) demonstrate that this circulation is persistent and then also existing during the early to late afternoon when tropical biomass burning activity is maximum (Giglio et al., 2003). Hence the exposed scenario has a high potential of reproducibility.

\section{Wet season case: 11-14 July 2003}

In their monthly climatology for the JJA season, Sauvage et al. (2005) found two distinct wind regimes and accompanying ozone distributions (their Fig. 15). In this section we analyze a case study representative of the "polluted" regime, covering 28\% of cases in JJA 2003 (the other 72\% are less interesting because no polluted layer is present). One must however remark that in 2003 especially few ozoneand CO-rich layers were detected. Indeed recent weekly ozonesonde measurements from Cotonou (Benin) performed in 2005 and 2006 in the framework of AMMA (http:// amma-international.org; contact: valerie.thouret@aero.obsmip.fr) showed that polluted layers are encountered in $45 \%$ of cases.

\subsection{MOZAIC profiles}

Figure 7 displays $\mathrm{O}_{3}, \mathrm{CO}$, wind parameters, and potential temperature for the descent phase of the Frankfurt-Lagos flight landed on 14 July 2003, 15:30 UTC. No relative humidity data is available for this flight.

Below $2000 \mathrm{~m}$ the monsoon layer (L1) is characterized by oceanic south-westerly wind (around $225^{\circ}$ ). Inside L1 appears a $700 \mathrm{~m}$-depth well-mixed layer $\left(\operatorname{see} \theta\right.$ and $\mathrm{O}_{3}$ ). The $7 \mathrm{~m} / \mathrm{s}$ jet near the surface is probably the signature of a local sea breeze that adds to the larger scale monsoon flux. This surface layer has no clear chemical signature, with a strong CO gradient (150-400 ppbv) but very low $\mathrm{O}_{3}$ concentration (less than $20 \mathrm{ppbv}$ ). Offshore platform fires can explain the $\mathrm{CO}$ maximum at low levels inside the monsoon flow. The low $\mathrm{O}_{3}$ concentration excludes the possibility of a chemically mature airmass. So L1 probably shows clean oceanic air perturbed by local and recent emissions.

The interesting layer in terms of medium-range transport of pollutants extends between 2000 and $4000 \mathrm{~m}$ a.s.l. (L2). The south-easterly $10-14 \mathrm{~m} / \mathrm{s}$ wind speed corresponds to the 

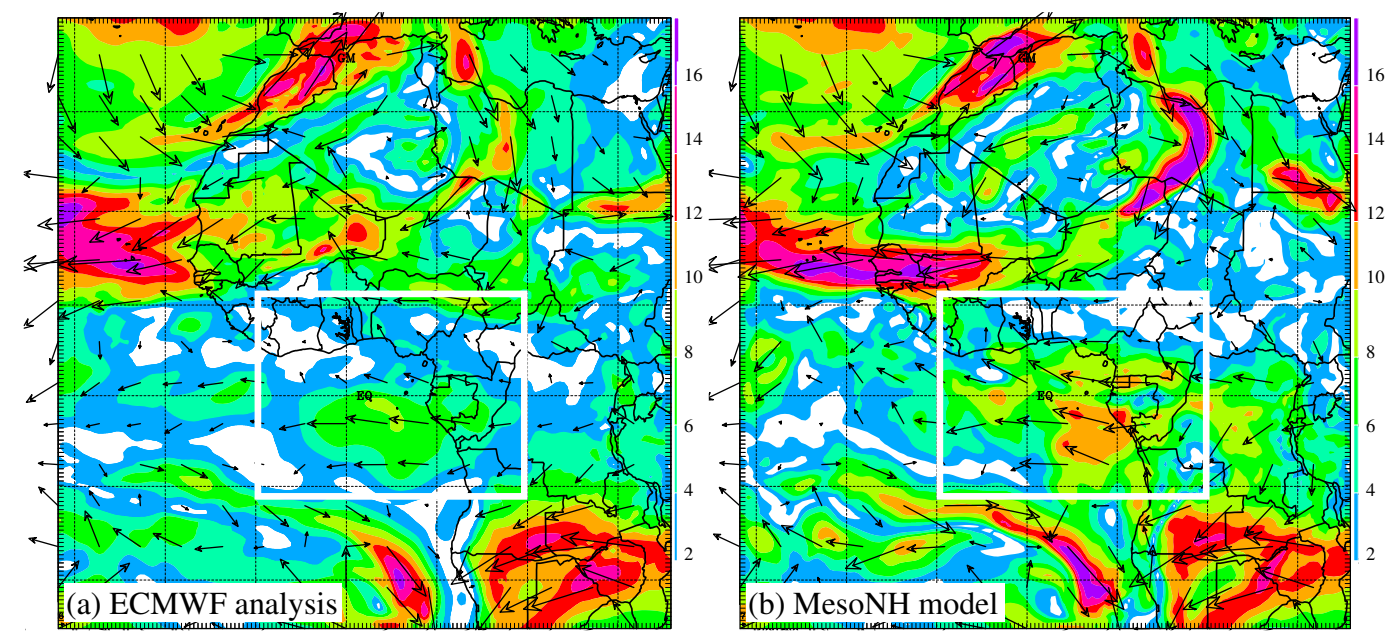

Fig. 8. Wind speed (colorscale in $\mathrm{m} / \mathrm{s}$ ) and vectors at $\mathrm{z}=3000 \mathrm{~m}$ a.s.1. on 14 July 2003, 12:00 UTC: (a) ECWMF analysis; (b) MesoNH $(+84 \mathrm{~h})$. (The white boxes highlight features under interest in the text.)

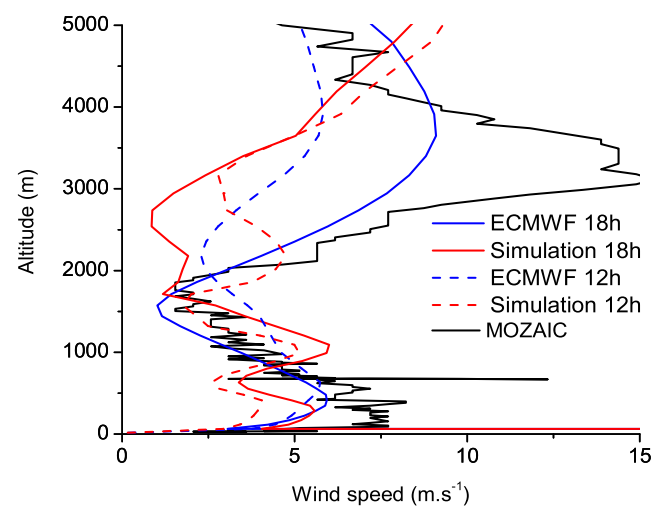

(a)

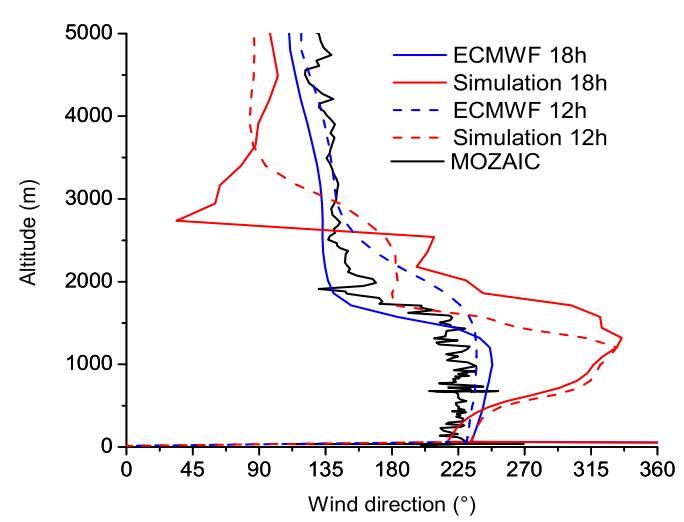

(b)

Fig. 9. MOZAIC descent profile (black, landing 14 July 2003, 15:30 UTC) and vertical profile over Lagos from ECMWF analyses and MesoNH simulation (14 July 2003, 12:00 and 18:00 UTC): (a) wind speed (m/s); (b) wind direction $\left({ }^{\circ}\right)$.

northern extension of the southern-hemisphere trades surmounting the low-level monsoon layer (as shown in the following). L2 presents both high $\mathrm{O}_{3}$ (more than $100 \mathrm{ppbv}$ ) and CO (up to $300 \mathrm{ppbv}$ ) Such values lye at the upper limit of the polluted type situation observed on monthly average (Sauvage et al., 2005). Considering the mixing ratio of $\mathrm{O}_{3}$ and CO, L2 cannot be explained by local pollution and is more representative of mature airmass loaded with pollutants few days ago (Chatfield and Delany, 1990). As in Sect. 3.1 we also performed particle releases from the surface to $500 \mathrm{~m}$ above, to investigate the possible influence of local pollution. No air mass uplift from below $1000 \mathrm{~m}$ was simulated. A model approach at regional scale is used to investigate the history of this air mass.

\subsection{Model evaluation}

The model started about 3.5 days before the MOZAIC flight landed, on 11 July 2003, 00:00 UTC, and ran during $96 \mathrm{~h}$ until 15 July, 00:00 UTC. Figure 8 shows a comparison at $\mathrm{z}=3000 \mathrm{~m}$ on 14 July $2003,12: 00$ UTC, between the ECMWF analysis and MesoNH (after 84h). The circulations at regional scale, and in particular the trade wind flow over the Gulf of Guinea (boxed in Fig. 8 - the feature of interest regarding transport, see Subsect. 4.3), are correctly reproduced - with however a significant overestimation in strength.

Figure 9 represents vertical profiles of wind at Lagos from the ECMWF analysis, the MesoNH simulation and the MOZAIC data. There is a poor agreement between observed and analyzed wind on the one hand (in rather good agree- 
ment with each other), and the simulated wind on the other hand. The model fails to reproduce some meso-scale features of the monsoon system such as the monsoon layer below $2000 \mathrm{~m}$ (L1). This might be due to insufficient resolution (here $50 \mathrm{~km}$ ) or a too long run (3.5 days), but anyway it illustrates the limitations of current models to capture the complex dynamics of the West African monsoon system (Sperber and Palmer, 1996) implying interaction of processes at different scales (Redelsperger et al., 2002), such as convection, evaporation or turbulence (Rowell et al., 1995). For instance idealized 2-dimensional approaches (e.g., Peyrillé et al., 2007 ) have pointed out the high sensitivity of the monsoon dynamics to some key features such as humid static energy distribution in the boundary layer (Wang and Eltahir, 2000), easterly waves, or horizontal advection of energies (Chou and Neelin, 2003). Concerning layer $\mathrm{L} 2 \mathrm{CO}_{3}$ maximum between 2000-4000 m), the model severely underestimates wind speed (by 8 to $10 \mathrm{~m} / \mathrm{s}$ ) but wind direction remains in the correct south-east quadrant (90-180 $)$ In Subsect. 4.3, it is explained why the differences in the wind field turn out to affect the trajectories only at the local scale around Lagos but not at the regional scale (the scale under interest in our study). Moreover the pathway and source location determined in the next paragraph are typical for such ozone enriched layers, according to the climatology by Sauvage et al. (2005) carried out with a Lagrangian model based on ECMWF wind fields (see their Fig. 15).

\subsection{Airmass origin}

Figure 10 shows trajectories ending in the L2 layer at Lagos on 14 July 2003, 18:00 UTC. MesoNH (Fig. 10a and b) reveals that two distinct groups of trajectories are clearly visible, with source locations both in Democratic Republic of Congo (DRC hereafter). For Group 1 - trajectories ending in the lower part of L2 - ascent from the surface occurs above the border between DRC and Congo, on 11 July, 00:00 UTC. Trajectories of Group 2 - ending in the upper part of L2 are uplifted further south-east in DRC. Fire occurrences were detected by ATSR between the 8 and 12 July for both ascent regions (Fig. 10a). DRC is a major place of biomass burning in July (http://dup.esrin.esa.int/ionia/wfa/index.asp; http: //modis-fire.umd.edu/data.asp), which can supply the two air masses with fire products.

The poor quantitative agreement between observations and model regarding wind (Fig. 9) put however in question the validity of the trajectories from MesoNH. Therefore we performed several tests. First, little changes in time $(6 \mathrm{~h})$ or location $\left( \pm 1^{\circ}\right)$ of the trajectory ending point do not affect the result (most of the time, the found trajectories are similar to Group 2.). Second, we also computed comparable backtrajectories with the model LAGRANTO (Wernli and Davies, 1997; Wernli 1997), on the base of the ECMWF analyzed wind-fields (that appeared to be closer to the observation). Those trajectories are shown in Fig. 10c. Despite the dis- crepancies in the wind fields over Lagos, LAGRANTO indicates very comparable path and source location. This is likely because the wind failures in MesoNH affect only a region close to Lagos, where the dynamics is complex. A more noticeable difference is the timing, since the particle need more than 5 days to travel from DRC to Lagos. This is an expected consequence of the difference in wind strength mentioned in Sect. 4.2 (Fig. 8). The climatological study by Sauvage et al. (2005) also indicated travel times longer than 4 days. There are however indications that 4 days may be sufficient to transport fire products to Lagos. Here fires are detected at the time of the trajectories start (Fig. 10a). Moreover Jonquières et al. (1998) have shown similar ozone and carbon monoxide concentrations after 4 days transport of air masses loaded with biomass burning products over Africa in a transport-chemistry study of the TROPOZ campaigns measurements. This however do not exclude that some air masses loaded with biomass burning emissions may also originate further south and participate to ozone and carbon monoxide enhancements persistent in monthly average over Lagos after a longer travel (Sauvage et al., 2005).

Another important difference between LAGRANTO and MesoNH is that, unlike MesoNH, LAGRANTO is not able to capture the ascent of the particles above DRC. For this reason MesoNH trajectories remain very informative. Given that MesoNH reveals uplift over DRC, and both MesoNH and LAGRANTO show trajectories linking DRC and Lagos, evidence is established here of a connexion between fires in the southern hemisphere and layer L2 over Lagos. The processes explaining the uplift of the two air masses (trajectory groups 1 and 2) to the altitude of transport by the south-easterlies are now investigated.

Figure 11a confirms the source location of Group 1 (at the Congo/DRC border) as an area where ascent exceeds $900 \mathrm{~m}$ within $6 \mathrm{~h}$, allowing the uplift of fire products to an altitude of $2500 \mathrm{~m}$ on 12 July, 12:00 UTC. In the time interval (06:00-12:00 UTC) Fig. 11b reveals an accumulation of 10 to $12 \mathrm{~mm}$ of convective precipitation over the same area. Thus the ascent of Group 1 is driven by wet convection in the ITCZ. Additional influence could be expected from lightning $\mathrm{NO}_{\mathrm{x}}$ emissions associated with convective cell. However LIS sensor did not detect any flash events associated with this convective cell. Recent studies seems to show that few lightning $\mathrm{NO}_{\mathrm{x}}$ are emitted below $4 \mathrm{~km}$ as outlined in the recent review on lightning $\mathrm{NO}_{\mathrm{x}}$ emission by Schumann and Huntrieser (2007). Moreover no trajectories were reflecting downward transport from the middle troposphere that could have allowed ozone related to lightning to mix down.

The strong uplift (500 to $700 \mathrm{~m}$ within $6 \mathrm{~h}$ ) affecting particle Group 2 is clearly visible in Fig. 12a. Unlike for Group 1, the uplfit cannot be linked to deep convection for none occurs at this time and place. The process generating this ascent line is actually, in mirror symmetry, the same as the baroclinic dynamics depicted in Sect. 3. Indeed Fig. 12b shows that this line coincides with a sharp meridional gradient of equivalent 

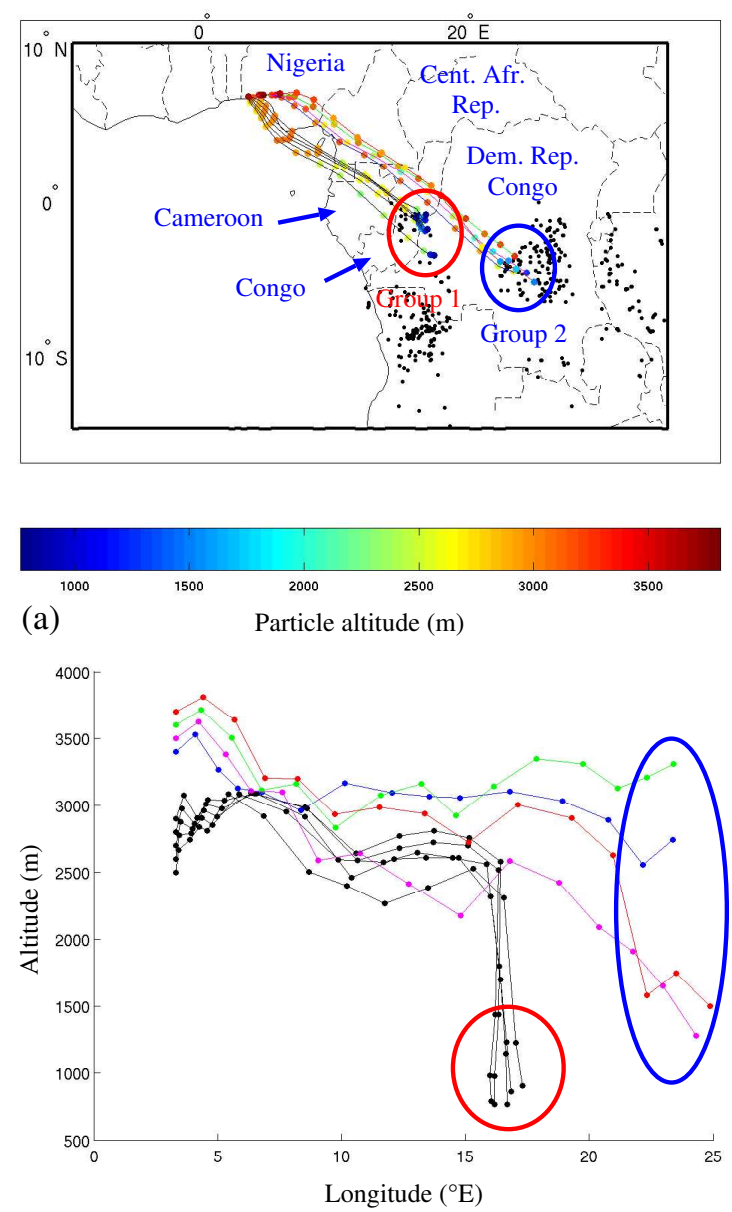

(b)

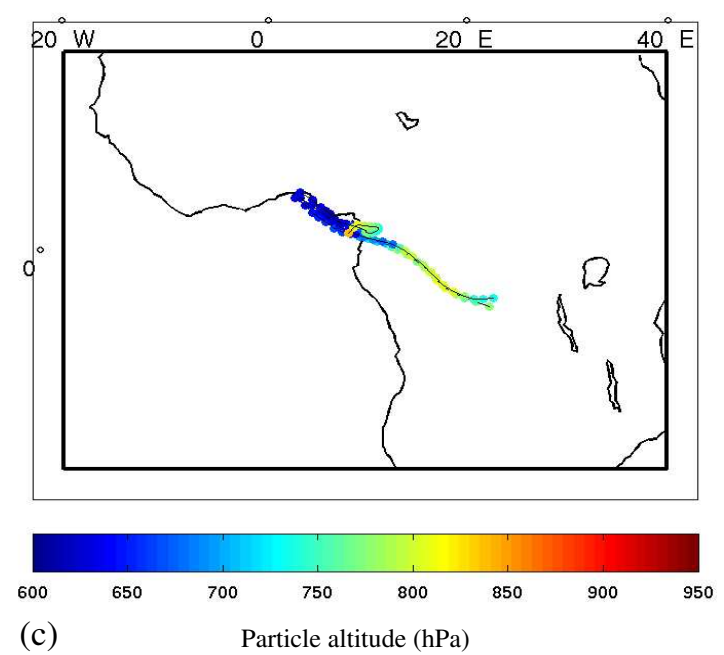

Fig. 10. Backtrajectories starting on 11 July 2003, 00:00 UTC and ending over Lagos on 14 July 2003, 18:00 UTC. Timestep: 6h. (a) MesoNH trajectories, horizontal projection. The colorscale indicates the altitude of the particles. The black dots mark biomass fires detected by ATSR between 9 and 12 July 2003. (b) MesoNH trajectories, zonal vertical projection (altitude in m). (c) LAGRANTO trajectories from ECMWF analyzed wind fields, ending in the layer $680-630 \mathrm{hPa}(3500-4000 \mathrm{~m})$. The colorscale indicates the altitude (pressure level) of the particles. 


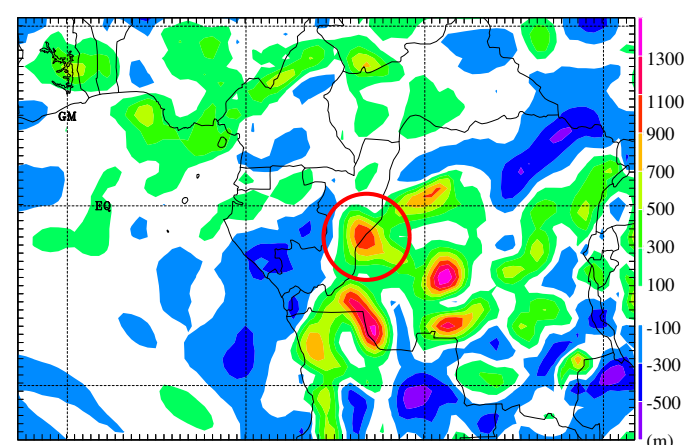

(a)

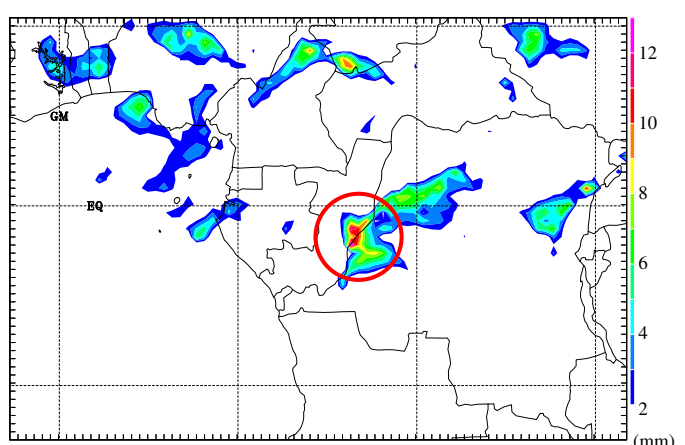

(b)

Fig. 11. (a) Air vertical displacement on 12 July 2003 00:00 UTC at $\mathrm{z}=2500 \mathrm{~m}$, integrated over the 6 preceding hours. (b) Convective precipitation on 12 July 2003 12:00 UTC accumulated over the 6 preceding hours. The circle locates the ascent of particle Group 1 (see Fig. 10 and text).

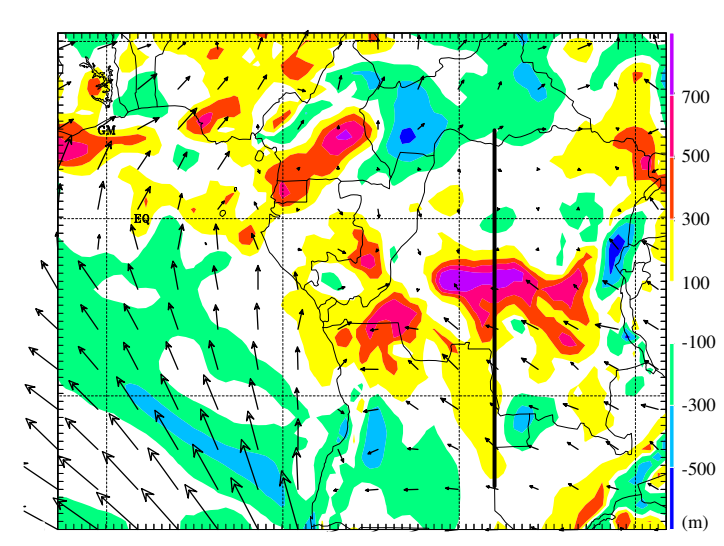

(a) $\quad \overrightarrow{13 \mathrm{~m} / \mathrm{s}}$

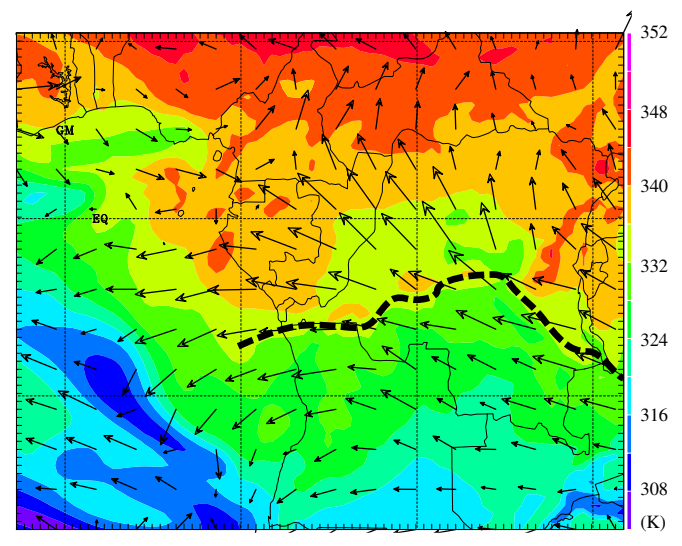

(b) $\overrightarrow{11 \mathrm{~m} / \mathrm{s}}$

Fig. 12. (a) Air vertical displacement (m) on 11 July 2003 between $06: 00$ and $12: 00$ UTC at $\mathrm{z}=2000 \mathrm{~m}$ and wind vectors at $12: 00 \mathrm{UTC} 20 \mathrm{~m}$ above ground level. (b) 11 July 2003, 12:00 UTC: Equivalent potential temperature (K) and wind vectors at $\mathrm{z}=2000 \mathrm{~m}$. The solid segment in (a) locates the vertical cross-section considered in Fig. 13. The dashed line in (b) delineates the Inter Tropical Front.

potential temperature $\left(\theta_{e}\right)$. The low values of $\theta_{e}(<335 \mathrm{~K})$ are found to the south and representative of the warm and dry continental south-easterlies. The high values $(>336 \mathrm{~K})$ on the north side are typical of the equatorial forest.

Figure 13 is a meridional vertical section across the ascent line and gives more details on its dynamics. The line corresponds to the convergence near the surface of the southeasterlies to the south with (weak) northerlies to the north. A closed vertical circulation is clearly visible between $3^{\circ} \mathrm{S}-$ $5^{\circ} \mathrm{N}$ and below $1500 \mathrm{~m}$ on the northside of the line. This circulation is symmetric to the solenoidal circulation depicted in Sect. 3, with its low-level branch oriented southwards and its upper return branch northwards. Figure 13b highlights the baroclinic nature of the circulation in response to the surface potential temperature and equivalent potential temperature gradients.
Again this pattern - that drives the processes of fireproduct injection in altitude - can be viewed as a baroclinic solenoidal circulation upon which the large-scale southeasterlies impinge. In this case however the cell is weaker than in the northern hemisphere during the dry season, because of weaker $\theta_{e}$ gradients, but is still a persistent feature of the diurnal cycle. An easterly jet is nevertheless simulated above the return branch, between 2000-2700 m, corresponding to the geostrophic adjustment (thermal wind balance) to the meridional surface gradient of temperature. This jet has actually been observed with radio-sondes data by Burpee (1975) and Janicot (1993). 


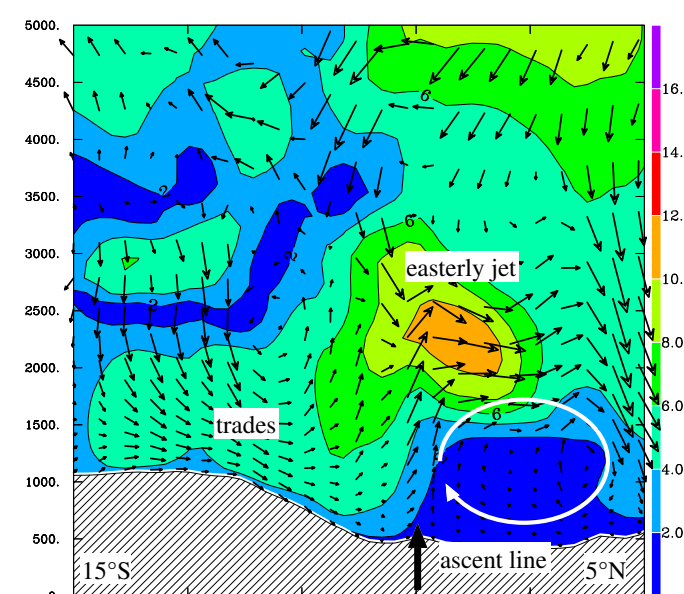

(a)

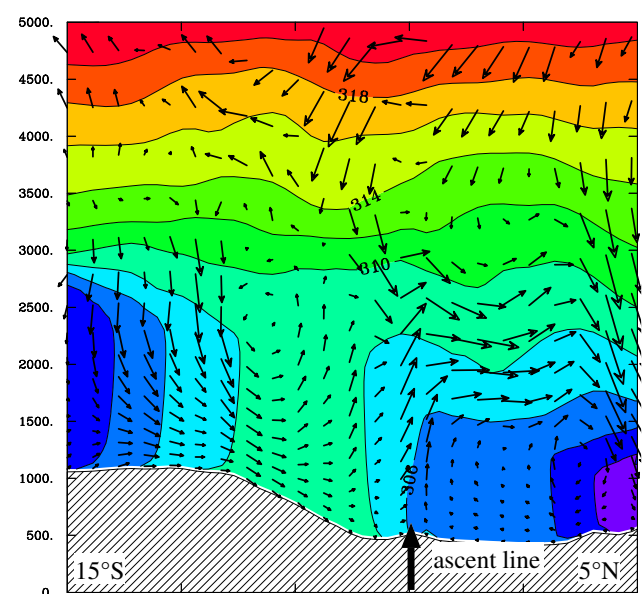

(b)

Fig. 13. Meridional vertical cross-section at $22^{\circ} \mathrm{E}$ (see location in Fig. 12a) on 11 July 2003, 12:00 UTC. (a) Longitudinal wind component (vectors) and total-wind speed (colorscale in $\mathrm{m} / \mathrm{s}$ ). (b) Potential temperature (colorscale in $\mathrm{K}$ ) - vectors as in (a).

\section{Conclusions}

A meso-scale model (MesoNH) was used to understand and describe the processes driving high ozone concentrations observed during both dry and monsoon season in monthly climatologies of vertical profiles over Lagos, obtained with the MOZAIC airborne measurements (Sauvage et al., 2005). This study focuses on ozone enhancements observed in the upper part of the lower troposphere, around $3000 \mathrm{~m}$. For that purpose two individual cases have been selected in the MOZAIC dataset as being representative of the climatological ozone enhancements, to be simulated and analyzed with on-line Lagrangian backtracking of air masses.

The evaluation of the simulated dynamical fields with insitu MOZAIC measurements and with ECMWF analysis has shown a good qualitative agreement for the dry season case. For the wet season there is less agreement, confirming some difficulties of current modeling to fully reproduce complex dynamical meso-scale systems such as the monsoon onset. However the signature of regional transport processes is correctly reproduced by the model, allowing to describe the dynamical processes responsible for ozone and carbon monoxide enhancement at Lagos during the two seasons.

This study points out the potential role of baroclinic lowlevel circulations present in the Inter Tropical Front (ITF) area, to uplift ozone precursors emitted by the surface (in particular from biomass burning) to higher altitude. These circulations are sketched in Fig. 14.

Two low-level cells (below $2000 \mathrm{~m}$ ), in mirror symmetry to each other with respect to the equator, form near $20^{\circ} \mathrm{E}$ and around $5^{\circ} \mathrm{N}$ and $5^{\circ} \mathrm{S}$ during the (northern hemisphere) dry and wet seasons respectively. Meridionally they extend over few hundred kilometers. They are caused by surface gradients - the warm dry surface being located poleward of the ITF and the cooler wet surface equatorward of the ITF. Those gradients induce in each hemisphere a thermal circulation cell around a zonal axis, with its lower branch pointing toward the dry region, i.e. poleward. Thorncroft and Blackburn (1999) and Parker et al. (2005) invoked this mechanism (in the northern hemisphere) as the cause of the African Easterly Jet, that develops aloft in geostrophic response to meridional temperature gradient in the low levels (thermal wind balance). In the sourthern hemisphere an easterly jet also exists (Burpee, 1975; Janicot, 1993), however of lesser intensity and zonal extension.

A convergence line (often termed Inter Tropical Front (ITF) or Discontinuity (ITD), Parker 2005 and references therein) exists between the poleward low-level branch of the thermal cell and the equatorward low-level branch of the Hadley cell (namely the Harmattan in the northern hemisphere, and south-easterlies in the southern hemisphere). Our main conclusion is to point out this line as a preferred location for fire products to be uplifted and injected into the lower free troposphere.

The free tropospheric transport that occurs then depends on the hemisphere and season. In the NH dry season, the AEJ allows transport of ozone and precursors westward to Lagos where fires are detected. In the NH monsoon (wet) season, fire products are transported from the southern hemisphere to Lagos by the south-easterly trade above the monsoon layer. Additionally ozone precursors uplifted by wet convection in the ITCZ can also mix to those uplifted by the baroclinic cell and be advected up to Lagos by the trade flow.

The scenarios of Fig. 14 are proposed on the basis of two case studies only. However these cases were chosen to be as representative as possible of the climatology established by Sauvage et al. (2005). The stationary nature of the surface gradients, the quasi-stationary character of the low- 

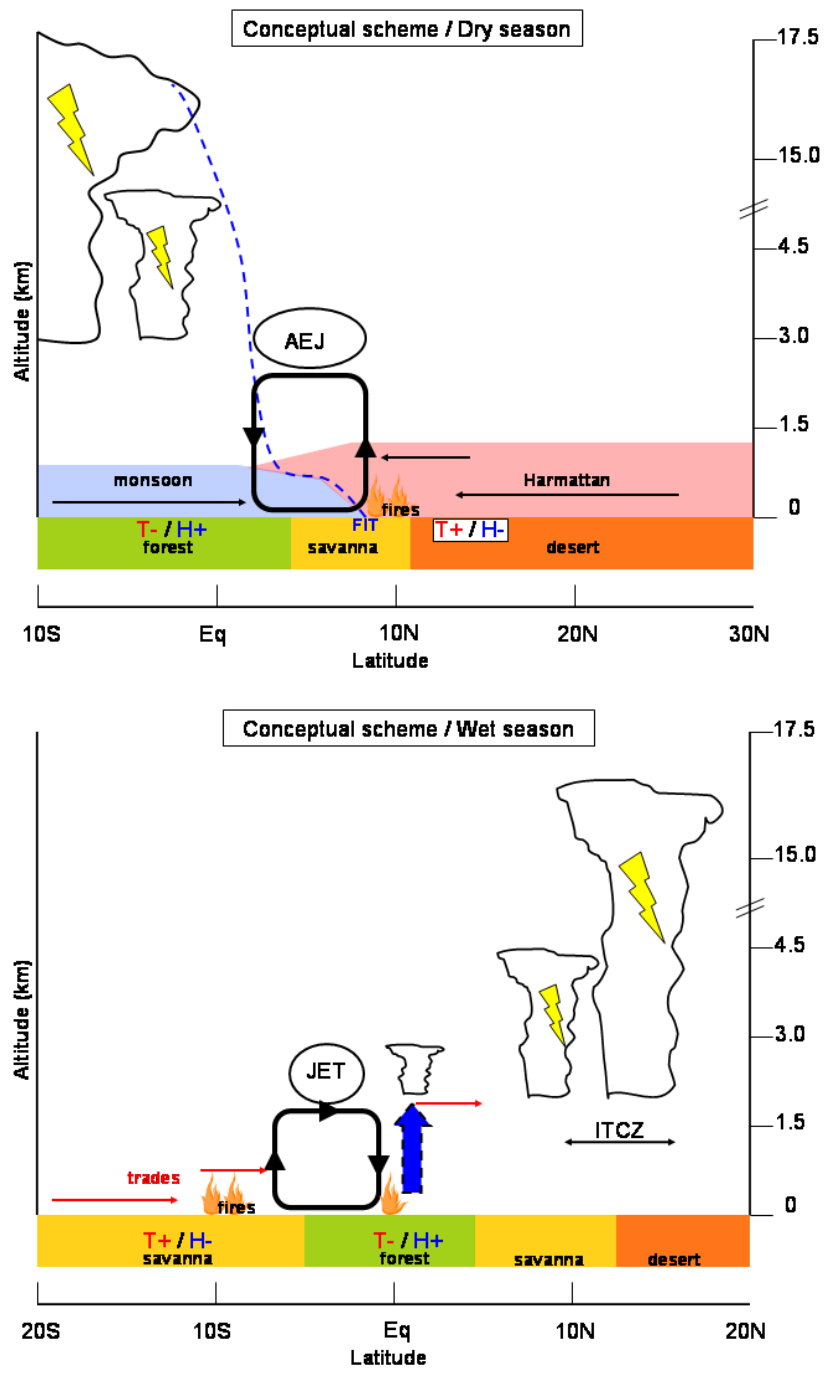

Fig. 14. Sketches for the injection of combustion products in the lower free-troposphere in Africa in the northern-hemisphere dry (DJF - fires in the NH - upper panel) and wet (JJA - fires in the $\mathrm{SH}$ - lower panel) season. The blue arrow (lower panel) symbolizes injection of pollutants by deep convection in the ITCZ.

tropospheric circulation, and its zonal quasi-uniformity (at least in the northern hemisphere between $10^{\circ} \mathrm{E}-30^{\circ} \mathrm{E}$ ), further support the idea that those scenarios are representative of a climatology of transport in Africa. Further studies in the frame of the AMMA campaign using a chemical-transport model should allow to quantify ozone production along the dynamical processes described in our study, and the relative contribution from fires emissions to other possible mechanisms that could contribute in ozone concentrations in the lower troposphere.
Acknowledgements. The authors acknowledge MOZAIC funding agencies, the European Commision, CNRS (France), Forschungszentrum Jülich (Germany), Météo-France, EADS (Airbus) and the airlines (Air France, Lufthansa, Austrian Airlines, and former Sabena who carry free of charge the MOZAIC equipment and perform the maintenance). The numerical resources were provided by IDRIS (CNRS). The authors thank T. van Noije and three anonymous referees for their very constructive reviews.

Edited by: P. Haynes

\section{References}

Andreae, M. O.: The influence of tropical biomass burning on climate and the atmospheric environment, in: Biogeochemistry of Global Change: Radiatively Active Trace Gases, edited by: Oremland, R. S., Chapman and Hall, New York, 113-150, 1993.

Bechtold, P., Kain, J., Bazile, E., Mascart, P., and Richard, E.: A mass flux convection scheme for regional and global models, Q. J. Roy. Meteor. Soc., 127, 869-886, 2001.

Bougeault, P. and Lacarrère, P.: Parameterization of orographyinduced turbulence in a meso-beta scale model, Mon. Wea. Rev., 117, 1870-1888, 1989.

Burpee, R.: Some features of synoptic-scale waves based on a composing analysis at gate data, Mon. Wea. Rev., 103, 921-925, 1975.

Chatfield, R. and Delany, A.: Convection links biomass burning to increased tropical ozone: However, models will tend to overpredict O3, J. Geophys. Res., 95, 18 473-18 488, 1990.

Chou, C. and Neelin, J.: Mechanisms limiting the northward extent of the northern summer monsoons over North America, Asia, and Africa, J. Climate, 16, 406-425, 2003.

Cuxart, J., Bougeault, P., and Redelsperger, J.-L.: A turbulence scheme allowing for mesoscale and large-eddy simulations, Q. J. Roy. Meteor. Soc., 126, 1-30, 2000.

Edwards, D. P., Emmons, L. K., and Gille, J. C.: Satellite-observed pollution from Southern Hemisphere biomass burning, J. Geophys. Res., 111, D14312, doi:10.1029/2005JD006 655, 2006.

Gal-Chen, T. and Sommerville, R.: On the use of a coordinate transformation for the solution of the Navier-Stokes equations, J. Comput. Phys., 17, 209-228, 1975.

Gheusi, F. and Stein, J.: Lagrangian description of air-flows using Eulerian passive tracers, Q. J. Roy. Meteor. Soc., 128, 337-360, 2002.

Giglio, L., Kendall, J. D., and Mack, R.: A multi-year active fire dataset for the tropics derived from TRMM VIRS, Int. J. Remote Sens., 24(22), 4505-4525, 2003.

Guichard, F., Petch, J., Redelsperger, J.-L., Bechtold, P., Chaboureau, J.-P., Cheinet, S., W., G., Grenier, H., Jones, C., Köhler, M., Piriou, J., Tailleux, R., and Tomasini, M.: Modelling the diurnal cycle of deep precipitating convection over land with cloud-resolving models and single columns models, Q. J. Roy. Meteor. Soc., 130, 3139-3172, 2004.

Hastenrath, S.: Climate and circulations of the tropics, D. Reidel, Dordrecht, 1985.

Jaeglé, L., Steinberger, L., Martin, R., and Chance, K.: Global partitioning of $\mathrm{NO}_{\mathrm{x}}$ sources using satellite observations: Relative roles of fossil fuel combustion, biomass burning and soil emissions, Faraday Discuss., 130, 407-423, 2005. 
Janicot, S.: Variability of dynamical fields over Africa (1970-1988); atlas for validation of general circulation models, Tech Note LMD, 187, 131 pp., 1993.

Jonquières, I., Marenco, A., Maalej, A., and Rohrer, F.: Study of ozone formation and transatlantic transport from biomass burning emissions over West Africa during the airborne Tropospheric Ozone campaigns TROPOZ I and TROPOZ II, J. Geophys. Res., 103, 19059-19074, 1998.

Kessler, E.: On the distribution and continuity of water substance in atmospheric circulation, Meteor. Monogr., 46, 165-170, 1969.

Lafore, J., Stein, J., Asencio, N., Bougeault, P., Ducrocq, V., Duron, J., Fischer, C., Héreil, P., Mascart, P., Redelsperger, J., Richard, E., and Vilà-Guerau de Arellano, J.: The Meso-NH atmospheric simulation system. Part I : Adiabatic formulation and control simulations, Ann. Geophys., 16, 90-109, 1998,

http://www.ann-geophys.net/16/90/1998/.

Marufu, L., Dentener, F., Lelieveld, J., Andreae, M., and Helas, G.: Photochemistry of the African troposphere: Influence of biomass-burning emissions, J. Geophys. Res., 105, 1451314 530, 2000.

Masson, V.: A physically-based scheme for the urban energy balance in atmospheric models, Boundary Layer Meteor., 94, 357397, 2000.

Morcrette, J.-J.: Radiation and cloud radiative properties in the European Center for Medium range Weather Forcasts forecasting system, J. Geophys. Res., 96, 9121-9132, 1991.

Newell, R., Thouret, V., Cho, J., Stoller, P., Marenco, A., and Smit, H.: Ubiquity of quasi-horizontal layers in the troposphere, Nature, 398, 316-319, 1999.

Noilhan, J. and Planton, S.: A simple parametrization of land surface precesses for meteorological models, Mon. Wea. Rev., 117, 536-549, 1989.

Parker, D., Thorncroft, C., Burton, R., and Diongue-Niang, A.: Analysis of the African easterly jet, using aircraft observations from the JET2000 experiment, Q. J. Roy. Meteor. Soc., 131, 1461-1482, 2005.

Peyrillé, P., Lafore, J.-P., and Redelsperger, J.-L.: An idealized framework to study the West African monsoon, Part I: Validation and key controlling factors, J. Atmos. Sci., 64, 2765-2782, 2007.
Redelsperger, J.-L., Diongue, A., Diedhou, A., Ceron, J.-P., Diop, M., Gueremy, J.-F., and Lafore, J.-P.: Multi-scale description of a Sahelian synoptic weather system representative of the West African monsoon, Q. J. Roy. Meteor. Soc., 128, 1229-1257, 2002.

Rowell, D., Folland, C., Maskell, K., and Ward, M.: Variability of summer rainfall over tropical North Africa, Q. J. Roy. Meteor. Soc., 121, 669-704, 1995.

Sauvage, B., Thouret, V., Cammas, J., Gheusi, F., Athier, G., and Nédélec, P.: Tropospheric ozone over Equatorial Africa: regional aspects from the MOZAIC data, Atmos. Chem. Phys., 5, 311335, 2005, http://www.atmos-chem-phys.net/5/311/2005/.

Schumann, U. and Huntrieser, H.: The global lightning induced nitrogen oxides source, Atmos. Chem. Phys., 7, 3823-3907, 2007, http://www.atmos-chem-phys.net/7/3823/2007/.

Singh, H. B., Herlth, D., Koyler, R.: Impact of biomass burning emissions on the composition of the South Atlantic troposphere: Reactive nitrogen and ozone, J. Geophys. Res., 101, $24203-$ $24220,1996$.

Sperber, K. and Palmer, T.: Interannual tropical rainfall variability in general circulation model simulations associated with the Atmospheric Model Intercomparison Project, J. Climate, 9, 27272750, 1996.

Thorncroft, C. and Blackburn, M.: Maintenance of the African easterly jet, Q. J. Roy. Meteor. Soc., 125, 763-786, 1999.

Tost, H., Jöckel, P., and Lelieveld, J.: Influence of different convection parameterisations in a GCM, Atmos. Chem. Phys., 6, 54755493, 2006, http://www.atmos-chem-phys.net/6/5475/2006/.

Wang, G. and Eltahir, E.: Biosphere-atmosphere interactions over West Africa. II: Multiple climate equilibria, Q. J. Roy. Meteor. Soc., 126, 1261-1280, 2000.

Wernli, H.: A Lagrangian-based analysis of extratropical cyclones. II: A detailed case-study, Q. J. Roy. Meteor. Soc., 123, 16771706, 1997.

Wernli, H. and Davies, H.: A Lagrangian-based analysis of extratropical cyclones. I: The method and some applications, Q. J. Roy. Meteor. Soc., 123, 467-489, 1997. 